\title{
Skill Education Program for Persons With Visual Disability in Indonesia (Study on the Rehabilitasi Sosial Bina Netra (RSBN) Orphanage in Malang City, East Java, Indonesia)
}

\author{
O Sukmana ${ }^{1}$ \\ \{oman@umm.ac.id\} \\ ${ }^{1}$ University of Muhammadiyah Malang, Indonesia
}

\begin{abstract}
Persons with Disabilities are anyone who experiences physical, intellectual, mental and sensory limitations for a long time in interacting with the environment can experience obstacles and difficulties to participate fully and effectively with other citizens based on equal rights. One of the efforts to increase the skill (capacity) of persons with disabilities is through coaching conducted by social rehabilitation institutions. This study aims to find out how the skill educational program for people with visual disabilities at the RSBN orphanage in Malang City, East Java, Indonesia. The study used a qualitative approach and qualitative descriptive research. Data collection techniques through interviews, observation and documentation. The subjects of the study were determined purposively namely the managers of the RSBN orphanage. The results showed that the skill education program for people with visual disabilities included: (1) mental physical guidance; (2) social guidance; (3) Skills guidance; (4) Placement in the community; and (5) Further coaching, so that people with visual disabilities have work and business skills after graduating from an institution. This skill educational program is able to make clients' visual disabilities become independent in carrying out their lives.
\end{abstract}

Keywords: Program, Education, Skill, Visual Disability.

\section{INTRODUCTION}

Jaeger and Bowman[1], states that disability is a problem that touches the lives of many people. Today there are an estimated 550 million people with disabilities worldwide. Most people know someone with a disability, and many of them have family members with disabilities. The number of people with disabilities continues to grow with population growth in many parts of the world. Grow, Alphas, Stephens, and Towers (2017) said that "It is generally claimed that visual disability has an adverse affect on quality of life"[2]. Compared to persons without disabilities, persons with visual impairments have a relatively low employment rate [3]. People with visual disabilities need social 
protection. Social protection programs have the potential to directly affect the lives of persons with disabilities [4].

The 1945 Constitution of the Republic of Indonesia guarantees that all Indonesian citizens have the right to a prosperous life, free choice of religion, protection and legal certainty, freedom of mind, education and health services, as well as the right to access and special treatment to obtain opportunities and the same benefits in order to achieve equality and fairness. This reflects that the state guarantees the fulfillment of the basic rights of all people, including people with disabilities, in order to obtain equal treatment and services in the life of the state. The right to access and special treatment is aimed at people with disabilities who in their lives need some assistance or special means to meet their needs.

World Health Organization (WHO) define disability as "A restriction or inability to perform an activity in the manner or within the range considered normal for a human being, mostly resulting from impairment". In addition to general understanding, WHO also states the definition of disability based on social models as follows: (1) Impairment, i.e. incompleteness or abnormality accompanied by its effects on certain functions. For example paralysis in the lower part of the body is accompanied by the inability to walk on both feet; and (2) Disability (handicap), is a limitation in certain activities as a result of social factors that only slightly or completely do not take into account the people who bear certain damage (weakness) and therefore expel those people from the flow of social activity.

According to Kristiansen, Vehmas, and Shakespeare [5] there are two interpretive models of disability, namely medical models and social models. Medical models include: (1) Full-Essentialist Individual Deficiency interpretation (FEID), which views that disability is caused by permanent medical characteristics that lead to a life of deficiency and 'abnormality', and (2) Part-Essentialist Individual Deficiency interpretation (PEID), which sees that disability is caused by the above medical characteristics, but conditions such as this can be corrected by changes in the social environment, so as to enable some degree of 'normal living'. Oliver [6] noted that "this medical approach produces definitions of disability which are partial and limited and which fail to take into account wider aspects of disability". While social models, include: (1) Politics of Disablement interpretation (POD), which views that disability is caused by systematic social practices that exclude impaired people from the activities of 'normal citizenship, and (2) Social Construction of Disablement interpretation (SCOD), which states that disabilities are affected by the way impairments are defined and associated with characteristics that are necessarily assumed to have a negative impact on personal identity, development and fulfillment.

Dorfman (2017) said that "disability is viewed socially as a personal tragedy or misfortune that requires charitable giving, pity, and paternalism from society"[7]. Ravindran, Brentnall, and Gilroy[8] statet that "Western conceptualisations of disability include three dominant philosophical approaches that shape disability service provision: the individual approach, the social approach and the holistic approach. The individual approach encompasses the (bio) medical model and the philanthropic model. The (bio) medical model promotes understanding disability as resulting from impairments that require fixing by health professionals. The philanthropic model focuses on charity and helping those with a disability. The social approach considers societal and environmental barriers to social inclusion as disabling. The social approach is beneficial in the political space in advocating for social inclusion and the rights of people with disabilities. The holistic approach consolidates these two perspectives, indicating that both impairments and environmental factors contribute to the disability experience". 
Whereas in the Law of the Republic of Indonesia Number 08 of 2016 concerning persons with disabilities it is stated that Persons with Disabilities are any person who experiences physical, intellectual, mental, and/or sensory limitations in the long term that in interacting with the environment may experience obstacles and difficulties to participate. fully and effectively with other citizens based on equal rights. Persons with disabilities can be grouped into four categories, namely: (1) Persons with physical disabilities; (2) People with intellectual disabilities; (3) People with mental disabilities; and (4) Persons with sensory disabilities. There are people with multiple disabilities, people with disabilities who have two or more types of disabilities, including deaf-speech and blindhearing disabilities. Both persons with physical, mental or dual disabilities all have rights [9].

In Indonesia, the rights of persons with disabilities are specifically regulated in Law of the Republic of Indonesia Number 8 of 2016 concerning Persons with Disabilities. According to the Law of the Republic of Indonesia Number 08 of 2016 states that Persons with Disabilities are any person who experiences physical, intellectual, mental, and / or sensory limitations for a long time in interacting with the environment can experience obstacles and difficulties to participate fully and effectively. with other citizens based on equal rights. The rights of persons with disabilities generally include: Right to life, Right to free from stigma, Right to privacy, Right to justice and legal protection, Right to education, Right to entrepreneurial and cooperative work, Right to health, Political right, Cultural and tourism rights, Right to social welfare, Right to accessibility, Right to public services, Right to protection from disasters, Right to habilitation and rehabilitation, Right to concession, Right to data collection, Right to live independently and involved in the community, Right to expression, Right to communicate, and obtain information, Right to move and citizenship, and free from action discrimination, neglect, torture and exploitation.

The Government and Regional Governments must provide social security, social protection and assistance to persons with disabilities. As a manifestation of the government's obligations, a service institution for people with disabilities was formed, that is the orphanage of Rehabilitasi Sosial Bina Netra (RSBN) in Malang. The Government and Regional Governments must provide social security, social protection and assistance to persons with disabilities. RSBN in Malang is one of the technical implementing units of the East Java Provincial Social Service that specifically carries out service and rehabilitation tasks for people with visual disability. The orphanage of RSBN in Malang has the main task of carrying out part of the tasks of the East Java Province Social Service in the fields of service, rehabilitation, assistance, guidance, development and resocialization of persons with visual disability, by providing physical, mental and social guidance and skills training, to develop the social capabilities of persons with visual disability. in order to become capable and useful citizens. The vision of the orphanage of RSBN in Malang is the realization of clients who have visual disabilities who are independent and able to work to improve their welfare.

This study aims to find out how the program description is carried out by the RSBN Intitution in Malang in an educational effort to improve the capacity of people with visual impairments [16].

\section{RESEARCH METHOD}

This study uses a qualitative approach [10], [11]) while the type of research is a qualitative descriptive study. The location of the study was conducted at the institution of Rehabilitasi Sosial Bina Netra (RSBN) in Malang, East Java. Subjects and research informants were determined based on purposive or judgmental sampling [12],[13],[14]. Purposive sampling technique is used in 
situations where a researcher uses certain considerations with specific objectives. Based on the above considerations, the subjects and informants in this study include: the manager of the orphanage on of RSBN Malang and clients with disabilities. The process of collecting data uses interview techniques, observation, and documentation. Given the data generated in the form of qualitative data, then to interpret it used an interpretive approach (interpretive approach). The stages of the qualitative data process refer to the views of Babbie, namely: (1) Coding Process, which is the process of classifying and categorizing data, which includes: open coding, axial coding and selective coding; (2) Memoing Process, i.e. the process of writing memos or notes to yourself and others involved in the project), including Code Notes, Theoretical Notes, and Operational Notes; and (3) Concept Mapping Process, which is the process of mapping relationships between various concepts. To test the validity of the data, the researcher focused on the credibility and confirmability criteria. The credibility technique used is observation persistence and referential adequacy. While the certainty technique (confirmability) uses a detailed description technique [15].

\section{RESULTS AND DISCUSSION}

The education program for clients with disabilities at the RSBN Orphanage in Malang is implemented within a period of between 2 and 3 years in accordance with the abilities of each client with a disability. The stages of the educational activity program include:

First, the Initial Approach Phase. This stage is intended to conduct orientation and consultation both for prospective clients who are in the community and prospective clients who come directly to the state hospital in Malang. At this stage also carried out identification of prospective clients, growing interest and motivation of prospective clients and to conduct client selection selection. For clients who are in the community, after this process they will be provided with a registration form (bio data) to be able to request a letter of recommendation from the village and the local Social Service. then the client can be escorted by the family, Social Service, village officials, or Volunteers to orphanage RSBN in Malang;

Second, the Acceptance Stage. This stage includes the activities of client registration, excavation, study of client problems through assessment, discussion and disclosure of problems through case conferences followed by placement of eligibility in the program. At this stage prospective clients who come to the RSBN orphanage in Malang will be selected administratively, follow the assessment process to find out the level of disability, physical and socio-economic conditions and readiness of the client to participate in social rehabilitation, continued discussion (case conference) the results of the assessment of prospective clients and end with a client placement in the guesthouse. If the client turns out to be ineligible due to inability to be educated or unable to train, then the client will be returned to the sending agency / family or can be temporarily resettled and then referred to an institution more suited to the client's needs;

Third, the Pengasrral Stage. Prospective clients who have met the requirements to get maid service. These services include shelter at the guesthouse, personal hygiene kits, cutlery and meals with a balanced menu 3 times a day and snacks. Clients also get uniforms and learning tools which include braille, reglate and stylus, duplek paper to record guidance material, OM sticks. Clients will also get the guesthouse cleaning tools. In case of illness, the Client receives health services either through soft medicines provided at the orphanage, eye health 
checks and general health at the Polyclinic every Friday, as well as examination of referrals to designated health installations (Community Health Centers, Hospitals);

Fourth, the Placement Phase in the Program (Program Implementation). At this stage, the client can participate in all types of social rehabilitation services according to the client's condition and ability. The program is divided into 5 (five) tiered classes which include: Preparatory Class A, Preparatory Class B, Elementary Class, Vocational Class, and Practical Class; and

Fifth, Program Termination Phase. At this stage the client can be returned to the family and community. This stage includes resocialization, provision of working capital assistance, work placement, further coaching and monitoring (home visit).

In an effort to improve the abilities and capacities of persons with disabilities so that they can live independently without being dependent on others, the state hospital in Malang implements various educational programs, which include: (1) Physical and Mental Guidance Program; (2) Social Guidance Program; and (3) Business / work skills guidance program.

First, the Physical and Mental Guidance Program. The physical and mental guidance program is intended to foster devotion to God and the realization of the client's will and ability to restore self-esteem, confidence, and emotional stability in order to create a personal maturity. This program includes: (a) Religious Guidance, where this guidance aims to make the client a human being who is devoted to Allah SWT and has good character as a person and community member; (b) Exercise, so that the client has a healthy physique, protected from various diseases; (c) Mobility orientation, so that clients are able to move from one place to another without the help of others; and (d) Activity Daily Living (ADL), which is guidance given to clients so that clients have the ability to carry out activities independently.

Second, the Social Guidance Program. This program is aimed at forming social attitudes based on solidarity and togetherness and social responsibility. The form of this program includes: (a) Braile Writing Practice, which is the introduction of braille letters as a medium of communication for blind persons with disabilities; (b) Practice in Indonesian, with the aim that the client can communicate using Indonesian that is good and right; (c) arithmetic exercises, aiming that the client can do calculations simply, easily, and quickly; (d) Citizenship Education, aims to be able to practice the values of Pancasila in everyday life; and (e) Entrepreneurship Training, which aims to foster enthusiasm; and

Third, the Business Skills Guidance Program (Work). This program is intended so that people with visual impairments have work and business skills to ensure a future that matches their abilities and environmental conditions. The forms of business / work skills guidance activities include: (a) Crafts, in which forms of business skills are provided to clients in the field of making mat; (b) Domestic Industry, with the aim of providing productive business skills to increase household income; (c) Massage skills program, in the form of: Message, which is a massage technique that uses a theory from Germany that aims to provide refreshment massage (tired massage and healing massage for sufferers who are indicative of the message); Shiatsu, a massage technique that prioritizes pressure to correct the body's condition from abnormalities towards normal as well as to improve blood circulation and increase endurance; and Reflection, which is a healing massage which is emphasized at certain laden points, especially in the legs, body and hands; (d) Band and Karawitan music art skills; (e) Koran reading skills (Qiroat); and (f) placement program in the community. 
To prepare graduates in the community, the RSBN orphanage in Malang took the following steps: (a) Resocialization, which was carried out during the 4 months leading up to social rehabilitation and completed work skills training. This activity is in the form of Work Learning Practices; (b) Each graduate is given working capital as work provision in accordance with the type of skills possessed; and (c) Advanced Coaching carried out through the local Social Service branch, Home Visit by RSBN orphanage officials in Malang, Correspondence in Braile letters, Development Training, and Reunion (Meeting). The further development is not only about job assessment, but also the adjustment of the attitude of the graduates further in the community. It is expected that with social rehabilitation and business skills training (work) while in the orphanage it will fulfill its future responsibly and be able to adjust its life challenges.

In summary, the form of educational programs in an effort to increase the capacity of clients with blind persons in orphanages RSBN Malang can be seen in the table as follows:

\section{Table :}

Types and Forms of Capacity Building Education Programs Persons with Net Disabilities in the Orphanage of RSBN Malang

\begin{tabular}{lll}
\hline Number & Type of Program & Forms of activity \\
\hline 1. & Physical and Mental Guidance & (a) Religious Guidance, \\
& Program & (b) Sports, \\
& (c) Mobility Orientation, and \\
& (d) Activity Daily Living (ADL) \\
S. & (a) Bral Guidance Program & (b) Indonesian language training, \\
& (c) Counting exercises, \\
& (d) Citizenship Education, and \\
& (e) Entrepreneurship Training. \\
& \\
Business Skills Guidance & (a) Handycrafts, \\
& (b) Domestic Industry, \\
& (c) Massage skills program, \\
& (d) Band and Karawitan music art skills, \\
& (e) Al-Quran / Qiro'at reading art skills; \\
& (f) Placement program in the \\
& (1) community.
\end{tabular}

Source: Research Results 2019 


\section{CONCLUSIONS}

The orphanage of RSBN of Malang is a government-owned institution that has the duty and function as a social service institution for clients with blind persons. In an effort to increase the capacity and capability of persons with blind disabilities, RSBN implements various stages of the process which includes the stages: initial approach, acceptance, resurrection, placement in the program, and termination which includes: resocialization, work placement, and further coaching (home visit). Whereas the educational program carried out in an effort to increase the ability (capacity) of clients with blind disabilities to live independently, includes three forms of programs, namely: Physical and Mental Guidance Program, Social Guidance Program; and the Business skills Guidance Program (work). The program implemented by the RSBN has succeeded in educating clients with disabilities to be able to live independently without being dependent on others.

\section{REFERENNCES}

[1] P. T. Jaegre and C. A. Bowman, Understanding Dissability. 2005.

[2] S. . La Grow and A. Alpas, V.; Stephens, C.; Towers, "Factors affecting perceived quality of life of older persons with self-reported visual disability," pp. 407-413, 2011.

[3] Y. . Jang, Y. T. . Wang, M. H. . Lin, and K. J. Shih, "Predictors of Employment Outcomes for People with Visual Impairment in Taiwan : The Contribution of Disability Employment Services," no. December, pp. 469-481, 2013.

[4] C. D. Aguilar, "Social protection and persons with disabilities," vol. 70, 2017.

[5] K. Kristiansen, S. Vehmas, and T. Shakespeare, Arguing about Disability. 2009.

[6] M. Oliver, The Politics of Disablment. Palgrave Macmillan, 1990.

[7] D. Dorfman, "Re-Claiming Disability: Identity , Procedural Justice , and the Disability Determination Process," vol. 42, no. 1, pp. 195-231, 2017.

[8] J. Ravindran, S.; Brentnall, J.; Gilroy, "Conceptualising disability : A critical comparison between Indigenous people in Australia and New South Wales disability service agencies," no. August 2016, pp. 367-387, 2017.

[9] A. Pawestri, "HAM INTERNASIONAL DAN HAM NASIONAL Aprilina Pawestri berarti cacat atau ketidakmampuan. Penggunaan dimanapun A . Latar Belakang Kelompok minoritas sebelumnya lebih kita kenal dengan penyandang ' cacat'. 2 Sebagai bagian dari masyarakat umunya , penyanda," vol. 2, no. 4, pp. 164-182, 2017.

[10] N. . K. Denzim and Y. S. Lincoln, Qualitative Research. .

[11] J. W. Creswell, "Qualitative Inqquiry and Research Design: Chosing Among Five Approaches." 2007.

[12] E. Babbie, The Basic of Social Research, vol. 91. 2008.

[13] W. L. Neuman, Basic Social Research Qualitative and Quantitative Approach. Pearson Education, Inc., 2007.

[14] R. K. Yin, Qualitative Research from Start to Finish. The Guilford Press, 2011.

[15] L. J. Moleong, Metode Penelitian Kualitatif. Remaja Rosdakarya, 2006.

[16] N.K. Juliantari, I.K. Sudarsana, N.K. Sutriyanti, I.N.T. Astawa, I.D.A.H. Putri, and K. Saddhono. "Educational Games Based in Information Technology as Innovation 
Evaluation Activity in Learning." In IOP Journal of Physics: Conference Series, vol. 1114 no. 1, p. 012041. IOP Publishing, 2018. 